\title{
Comparison of an Immunochromatographic Assay Kit with DAS-ELISA for Large-Scale Diagnosis and Molecular Discrimination of Satsuma Dwarf Virus Collected from Citrus Orchards
}

\author{
Mitsuhiro Kato $\mathbb{D}^{1 *}$, Kenta Tomimura $\mathbb{D}^{2}$, and Kanako Ishii ${ }^{1}$ \\ ${ }^{I}$ Shizuoka Prefectural Research Institute of Agriculture and Forestry, Fruit Tree Research Center, Mobata, Shimizu, \\ Shizuoka 424-0101, Japan \\ ${ }^{2}$ Institute of Fruit Tree and Tea Science, National Agriculture and Food Research Organization (NARO), Okitsu, Shi- \\ mizu, Shizuoka 424-0292, Japan
}

(Received on June 4, 2020; Revised on August 11, 2020; Accepted on August 16, 2020)

Satsuma dwarf virus (SDV) seriously damages citrus production by reducing the quality and yield of fruit. To avoid contamination with SDV, mother trees are checked to be SDV-free in advance of nursery tree distribution. In this study, we compared an immunochromatographic assay (ICA) kit with double-antibody sandwich enzyme-linked immunosorbent assay (DASELISA) for large-scale diagnosis of SDV in orchardgrown trees in Shizuoka Prefecture, Japan. The two methods gave conflicting results for 11 of 1,705 samples, all of which were negative by DAS-ELISA but positive by ICA. The samples scored as positive by either DASELISA or ICA were analyzed by reverse transcription polymerase chain reaction and all were confirmed to be positive. These results validate the use of ICA as a screening method for large-scale diagnosis. Strain discrimination revealed that 16 of 22 isolates belonged to SDV, while citrus mosaic virus (CiMV) infection only and co-infection (SDV and CiMV) were in a minority.

\footnotetext{
*Corresponding author.

Phone) +81-54-376-6154, FAX) +81-54-376-5186

E-mail) mitsuhiro1_kato@pref.shizuoka.lg.jp

ORCID

Mitsuhiro Kato

https://orcid.org/0000-0001-6061-9807

Kenta Tomimura

https://orcid.org/0000-0002-3718-4523

(c) This is an Open Access article distributed under the terms of the Creative Commons Attribution Non-Commercial License (http:// creativecommons.org/licenses/by-nc/4.0) which permits unrestricted noncommercial use, distribution, and reproduction in any medium, provided the original work is properly cited.
}

Articles can be freely viewed online at www.ppjonline.org.
Keywords : DAS-ELISA, immunochromatographic assay kit, large-scale diagnosis, satsuma dwarf virus, strain discrimination

Handling Editor : Seung-Kook Choi

Satsuma dwarf virus (SDV) seriously damages citrus production by reducing fruit quality and yield. Because it is a graft-transmissible disease, SDV prevalence has increased through the use of infected rootstocks and scions. SDV has been found in citrus production fields in Japan, China, Korea, and Turkey (Azeri, 1973; Kim et al., 2001; Ushiyama and Ogaki, 1970; Zhou et al., 1990). SDV-infected satsuma mandarin (Citrus unshiu (Swingle) Marcow.) forms boator spoon-shaped leaves (Ushiyama and Ogaki, 1970); however, depending on citrus cultivar, disease symptoms may not appear even if the material is infected. Therefore, it is important to diagnose SDV infection to enable the distribution of virus-free nursery plants.

Nomura et al. (2000) reported SDV diagnosis of young shoots collected from citrus orchards in Shizuoka Prefecture, Japan, using a double antibody sandwich enzymelinked immunosorbent assay (DAS-ELISA) (Voller et al., 1976). However, DAS-ELISA requires laboratory conditions and special equipment, uses many reagents, and is very labor intensive and time consuming. An immunochromatographic assay (ICA) kit has been developed that enables simple and rapid assays (Kusano et al., 2007) and has since been widely used for SDV detection.

Recently, SDV (order Picornavirales, family Secoviridae, genus Sadwavirus) was reclassified as the only one species of Sadwavirus (Thompson et al., 2017). Citrus mosaic 
virus (CiMV) and navel orange infectious mottling virus (NIMV) induce similar symptoms on satsuma mandarin (Tanaka and Yamada, 1972). However, CiMV and NIMV were not approved as separate species by the International Committee on Taxonomy of Viruses, but considered to be distantly related strains of SDV owing to their biological, serological and genomic properties (Fauquet et al., 2005).

CiMV is widely distributed in citrus production fields, mainly in Wakayama Prefecture in the mid-western part of Japan (Inuma and Tomimura, 2016). The distribution of SDV and related strains in other areas, in particular in eastern Japan including Shizuoka Prefecture, has not been investigated.

Here, we assessed the diagnostic value of ICA as an alternative to DAS-ELISA for the large-scale detection of SDV in a multi-year survey. We compared both screening methods with reverse transcription polymerase chain reaction (RT-PCR), which is the most sensitive detection method (Iwanami, 2010; Shimizu and Miyoshi , 2002; Shimomura and Noguchi, 2003). Using positive samples detected by ICA in this study, we also assessed the population diversity of SDV and related strains in Shizuoka Prefecture.

Young shoots were collected from 1,705 citrus trees (600 in 2011, 736 in 2012, and 369 in 2019) from commercial orchards in Shizuoka Prefecture, Japan. The tested citrus species and cultivars are listed in Table 1. Each sample was assayed by DAS-ELISA and ICA. The samples collected in 2012 and 2019 that were scored as positive by either of these methods were then tested by RT-PCR. DASELISA was performed with a commercial antibody (Japan Plant Protection Association, Tokyo, Japan) according to the manufacturer's instructions and published methods (Clark and Adams, 1977; Takahashi, 1988). Briefly, all DAS-ELISA tests were carried out in 96-well microtiter plates (Thermo Fisher Scientific Inc., Roskilde, Denmark). Sample preparation for DAS-ELISA tests were carried out as follows. Three $5 \mathrm{~mm}$ stainless beads and $3 \mathrm{ml}$ of $0.1 \mathrm{M}$ sodium citrate buffer ( $\mathrm{pH}$ 7.0) were previously prepared in $15 \mathrm{ml}$ polypropylene tubes. Citrus leaf tissue $(0.3 \mathrm{~g})$ and $10 \mathrm{~mm}$ stainless beads were added. The leaf material was disrupted using a Shake Master (Bio Medical Science, Tokyo, Japan) with the disruption condition of $110 \mathrm{rpm}, 2$ min. After the disruption of citrus leaf tissue, the grinding fluid were removed into a $2 \mathrm{ml}$ microtube, and centrifuged at approximately $15,000 \times \mathrm{g}, 10 \mathrm{~min}, 10^{\circ} \mathrm{C}$. The resultant supernatant were kept at $4^{\circ} \mathrm{C}$ until ELISA test.

Plates were coated with the antibody by incubating them with a solution $(200 \mu \mathrm{l}$ per well) containing $10 \mu \mathrm{g}$ antibody $/ \mathrm{ml}$ in carbonate buffer $(\mathrm{pH} 9.6)$ for $4 \mathrm{~h}$ at $30^{\circ} \mathrm{C}$ and then at $4^{\circ} \mathrm{C}$ overnight. Plates were washed with phosphatebuffered saline containing $0.05 \%$ Tween 20 (PBST) three times. The samples were added to individual wells; the plate was then incubated at $30^{\circ} \mathrm{C}$ for $2 \mathrm{~h}$ and afterward $4^{\circ} \mathrm{C}$ overnight. Wells were again washed three times with PBST. Alkaline phosphatase-conjugated antibody was then added to each well and the plate was incubated at $30^{\circ} \mathrm{C}$ for $4 \mathrm{~h}$. After three washes with PBST, alkaline phosphatase substrate (p-nitrophenyl phosphate) at a concentration of $1 \mathrm{mg} / \mathrm{ml}$ in diethanolamine buffer $(\mathrm{pH} 9.8$ ) was added to each well and the mixture was incubated for $1 \mathrm{~h}$ at room temperature. The optical density of each well was measured with a Sunrise Remote microplate reader (Wako Chemicals, Osaka, Japan) at $405 \mathrm{~nm}$. A sample was scored as positive if its absorbance value was $\geq 2$ times that of the healthy controls, and as weakly positive if it was 1.52 times that of the healthy controls.

ICA assays were carried out using an SDV chromato kit (Mizuho Medy Co., Ltd., Saga, Japan) (https://www. mizuho-m.co.jp/en/) according to the manufacturer's instructions. Each $0.1 \mathrm{~g}$ sample was homogenized in $500 \mu \mathrm{l}$ of $0.1 \mathrm{M}$ sodium citrate buffer ( $\mathrm{pH} 7.0$ ) containing $0.1 \%$ sodium azide with an automatic macerating machine (Ide et al., 2011). Then, 3 drops of the extract were applied to the test plate. After $15 \mathrm{~min}$, positive bands were identified visually.

Total RNA was extracted from $0.05 \mathrm{~g}$ of young leaves using ISOGEN (Nippon Gene, Tokyo, Japan) and an RNeasy Plant Mini Kit (Qiagen, Hilden, Germany) according to the manufacturers' instructions. Young citrus leaves were ground with $1 \mathrm{ml}$ ISOGEN solution or $450 \mu 1$ Buffer RLT containing $1 \% \beta$-mercaptoethanol using a mortar and pestle. RT-PCR for detection SDV species was carried out using a Qiagen OneStep RT-PCR kit (Qiagen). Amplification was carried out in a $15-\mu 1$ total reaction volume with $1 \mu \mathrm{M}$ forward and reverse primers (FW146 and RV488) (Iwanami, 2010) and $1 \mu 1$ of RNA extract according to the manufacturer's protocol. Primer pair of FW146 and RV488 could detect all SDV species including CiMV and NIMV strains. Amplification conditions were as follows: reverse transcription at $50^{\circ} \mathrm{C}$ for $30 \mathrm{~min}$, initial denaturation at $95^{\circ} \mathrm{C}$ for $15 \mathrm{~min}$, and 40 cycles of denaturation at $94^{\circ} \mathrm{C}$ for $30 \mathrm{~s}$, annealing at $54^{\circ} \mathrm{C}$ for $30 \mathrm{~s}$, and extension at $72^{\circ} \mathrm{C}$ for $90 \mathrm{~s}$, and a final extension at $72^{\circ} \mathrm{C}$ for $10 \mathrm{~min}$. Amplification products were analyzed by electrophoresis on a $2 \%$ agarose gel for $1 \mathrm{~h}$ at $50 \mathrm{~mA}$ and visualized with GelRed (Biotium, Fremont, CA, USA).

RT-PCR for strain discrimination was carried out with strain-specific primers (Table 2) (Inuma and Tomimura, 2016) using a PrimeScript OneStep RT-PCR kit ver.2 
Table 1. List of citrus variety and the number of trees used for SDV detection in this study

\begin{tabular}{|c|c|c|}
\hline Sampling year & Citrus species or cultivar & $\begin{array}{l}\text { No. of trees } \\
\text { tested }^{\mathrm{a}}\end{array}$ \\
\hline \multirow[t]{6}{*}{2011} & Satsuma mandarin (Citrus unshiu (Swingle) Marcow.) & $456(58)$ \\
\hline & Hyuga-natsu (C. tamurana hort. ex Tanaka) & $22(2)$ \\
\hline & Shiranui $[(C$. unshiu $($ Swingle) Marcow. $\times$ C. sinensis L. Osbeck $) \times C$. reticulata Blanco $]$ & 4 \\
\hline & Harumi $[(C$. unshiu $($ Swingle $)$ Marcow. $\times$ C. sinensis L. Osbeck $) \times$ C. reticulata Blanco $]$ & 1 \\
\hline & Unknown & 117 \\
\hline & Sub-total & $600(60)$ \\
\hline \multirow[t]{7}{*}{2012} & Satsuma mandarin (C. unshiu (Swingle) Marcow.) & $406(46)$ \\
\hline & Hyuga-natsu (C. tamurana hort. ex Tanaka) & $21(1)$ \\
\hline & Konta (Fortunella crassifolia Swingle) & 11 \\
\hline & Suruga Elegant (C. natsudaidai) & 9 \\
\hline & Shiranui $[(C$. unshiu $($ Swingle) Marcow. $\times$ C. sinensis L. Osbeck $) \times C$. reticulata Blanco $]$ & 1 \\
\hline & Unknown & $288(1)$ \\
\hline & Sub-total & $736(48)$ \\
\hline \multirow[t]{10}{*}{2019} & Satsuma mandarin (C. unshiu (Swingle) Marcow.) & $323(22)$ \\
\hline & Harumi $[(C$. unshiu $($ Swingle) Marcow. $\times$ C. sinensis L. Osbeck $) \times$ C. reticulata Blanco $]$ & 23 \\
\hline & Shiranui $[(C$. unshiu $($ Swingle) Marcow. $\times$ C. sinensis L. Osbeck $) \times$ C. reticulata Blanco $]$ & 12 \\
\hline & 'Lisbon' lemons (C. limon L. Burm. f. cv. Lisbon) & 3 \\
\hline & Kawano natsudaidai (C. natsudaidai) & 2 \\
\hline & $\begin{array}{l}\text { Setoka }\{[(\text { C. unshiu }(\text { Swingle }) \text { Marcow. } \times \text { C. sinensis L. Osbeck }) \times(C \text {. nobilis Lour. } \times \text { C. deliciosa } \\
\text { Ten. })] \times \text { Murcott }\}\end{array}$ & 2 \\
\hline & Suruga Elegant (C. natsudaidai) & 2 \\
\hline & Lemon (Citrus sp.) & 1 \\
\hline & Ohta Ponkan (C. reticulata Blanco) & 1 \\
\hline & Sub-total & $369(22)$ \\
\hline Total & & $1,705(130)$ \\
\hline
\end{tabular}

${ }^{a}$ Number of citrus trees judged satsuma dwarf virus (SDV) positive by double-antibody sandwich enzyme-linked immunosorbent assay and/or immunochromatographic assay are in parentheses.

(Takara, Shiga, Japan) according to the manufacturer's instructions. Amplification conditions were as follows: reverse transcription at $50^{\circ} \mathrm{C}$ for $30 \mathrm{~min}$, initial denaturation at $94^{\circ} \mathrm{C}$ for $2 \mathrm{~min}$, followed by 35 amplification cycles of denaturation at $94^{\circ} \mathrm{C}$ for $30 \mathrm{~s}$, annealing at $60^{\circ} \mathrm{C}(\mathrm{SDV})$ or $58^{\circ} \mathrm{C}$ (CiMV and NIMV) for $30 \mathrm{~s}$, and extension at $72^{\circ} \mathrm{C}$ for $90 \mathrm{~s}$, and a final extension at $72^{\circ} \mathrm{C}$ for $10 \mathrm{~min}$. Amplification products were separated by electrophoresis, and strains were identified by amplicon size. Strains SDV (S-58) and CiMV (NG2) were used as positive controls.

Among the 600 samples tested in 2011, 47 samples (7.8\%) were scored as positive by both DAS-ELISA and ICA, and $540(90.0 \%)$ were scored as negative by both methods (Table 3 ). Another 8 samples (1.3\%) were scored as weakly positive by DAS-ELISA and positive by ICA.
The two methods gave conflicting results for 5 samples $(0.8 \%)$, all of which were negative by DAS-ELISA but positive by ICA.

Among the 736 samples tested in 2012, 34 samples $(4.6 \%)$ were scored as positive by both DAS-ELISA and ICA and $688(93.5 \%)$ were scored as negative by both methods (Table 3). Another 9 samples (1.2\%) were scored as weakly positive by DAS-ELISA and positive by ICA. The two methods gave conflicting results for 5 samples $(0.7 \%)$, all of which were negative by DAS-ELISA but positive by ICA.

Among the 369 samples tested in 2019, 21 samples (5.7\%) were scored as positive by both DAS-ELISA and ICA, and $347(94.0 \%)$ were scored as negative by both methods (Table 3). The two methods gave conflicting re- 
Table 2. Summary of primer combination and expected DNA band size in SDV detection by strain specific RT-PCR

\begin{tabular}{llcr}
\hline \multirow{2}{*}{ Strain } & \multicolumn{2}{c}{ Primer combination } & \multicolumn{2}{c}{ Expected DNA band size $^{\mathrm{a}}$} \\
\cline { 2 - 4 } & Forward primer & Reverse primer & 1,075 \\
SDV & SDR2CPL1P & DT30 & 1,623 \\
CiMV & CIR2CPL3P & DT30 & 1,127 \\
NIMV & NIR2CPL1P & DT30 & 1,10 \\
\hline
\end{tabular}

RT-PCR, reverse transcription polymerase chain reaction.

${ }^{a}$ Expected DNA band sizes were estimated from the sequences of satsuma dwarf virus (SDV; accession no. AB009959), citrus mosaic virus (CiMV; accession no. AB465581) and navel orange infectious mottling virus (NIMV; accession no. AB465583) strains (Iwanami, 2010).

Table 3. Comparison of detection performance using DAS-ELISA and ICA in satsuma dwarf virus

\begin{tabular}{|c|c|c|c|c|}
\hline \multirow{2}{*}{ Year } & \multirow{2}{*}{ ICA test result } & \multicolumn{3}{|c|}{ No. of DAS-ELISA results $(\%)^{a}$} \\
\hline & & Positive & Weakly positive & Negative \\
\hline \multirow[t]{2}{*}{2011} & Positive & $47(7.8)$ & $8(1.3)$ & $5(0.8)$ \\
\hline & Negative & 0 & 0 & $540(90.0)$ \\
\hline \multirow[t]{2}{*}{2012} & Positive & $34(4.6)$ & $9(1.2)$ & $5(0.7)$ \\
\hline & Negative & 0 & 0 & $688(93.5)$ \\
\hline \multirow[t]{2}{*}{2019} & Positive & $21(5.7)$ & 0 & $1(0.3)$ \\
\hline & Negative & 0 & 0 & $347(94.0)$ \\
\hline
\end{tabular}

${ }^{a}$ Percentage of citrus trees judged by double-antibody sandwich enzyme-linked immunosorbent assay (DAS-ELISA) and immunochromatographic assay (ICA) are in parentheses.

sults for 1 sample $(0.3 \%)$, which was negative by DASELISA but positive by ICA.

Samples collected in 2012 and 2019 that were scored as positive by either DAS-ELISA or ICA were tested by RTPCR (Table 4). All of the 48 such samples in 2012 and 22 in 2019 were positive by RT-PCR, including the 5 samples in 2012 and 1 sample in 2019 scored as negative by DASELISA. We also tested 22 samples in 2019 that were scored as negative by ICA and found all of them to be also negative by RT-PCR.

Amplicons were detected in all the 22 SDV-positive samples from the ICA test in 2019 with RT-PCR primers FW146 and RV488, which could amplify all SDV species including CiMV and NIMV strains (Iwanami, 2010). Analysis of these 22 samples with primers specific for SDV, CiMV, or NIMV detected SDV in 16 samples, CiMV in 2 samples, and co-infection with SDV and CiMV in 1 sample (Fig. 1). NIMV was not detected (data not shown). In three samples, no virus strain was detected with any of the strain-specific primers; a common-sequence amplicon was directly sequenced using both amplification primers, and CiMV was detected in all of them. In a previous study by Iwanami et al. (2001), isolates that could not be char-
Table 4. Correlation between ICA and RT-PCR results in satsuma dwarf virus detection

\begin{tabular}{cccc}
\hline \multirow{2}{*}{ Year } & \multirow{2}{*}{$\begin{array}{c}\text { ICA test } \\
\text { result }\end{array}$} & \multicolumn{2}{c}{ RT-PCR result } \\
\cline { 3 - 4 } 2012 & Positive & 48 & 0 \\
& Negative & $-{ }^{\mathrm{b}}$ & $-^{\mathrm{b}}$ \\
\multirow{2}{*}{2019} & Positive & 22 & 0 \\
& Negative & 0 & 22 \\
\hline
\end{tabular}

${ }^{a}$ Samples positive by immunochromatographic assay (ICA) were analyzed by reverse transcription polymerase chain reaction (RTPCR).

${ }^{b}$ Not tested.

acterized by biological properties would be identified as CiMV by analyzing sequence diversity. Considering the fact that we could not discriminate three samples when we used CiMV specific primer pair in this study and the report of Iwanami et al (2001), the diverse population of CiMV may reflect. The understanding of CiMV diversity would be revealed the demarcation of SDV species.

Since ICA was launched commercially in 2008 , it has 
A
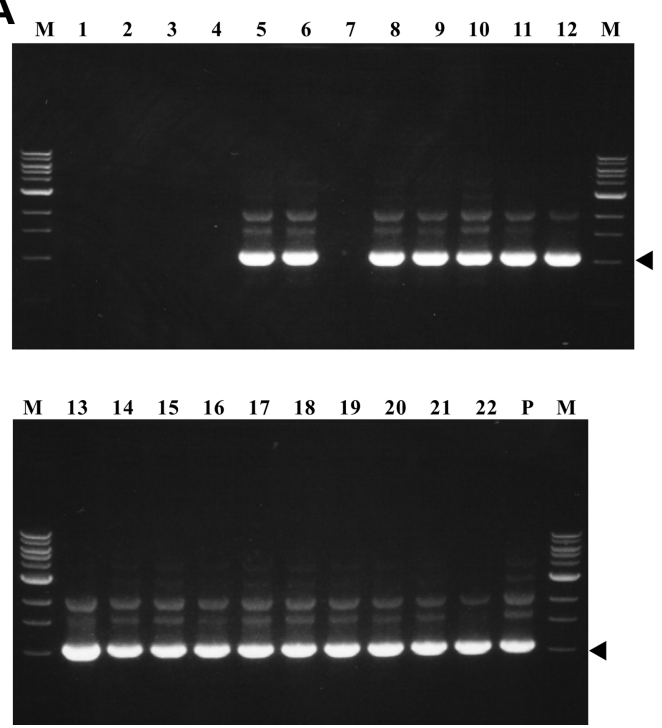

B
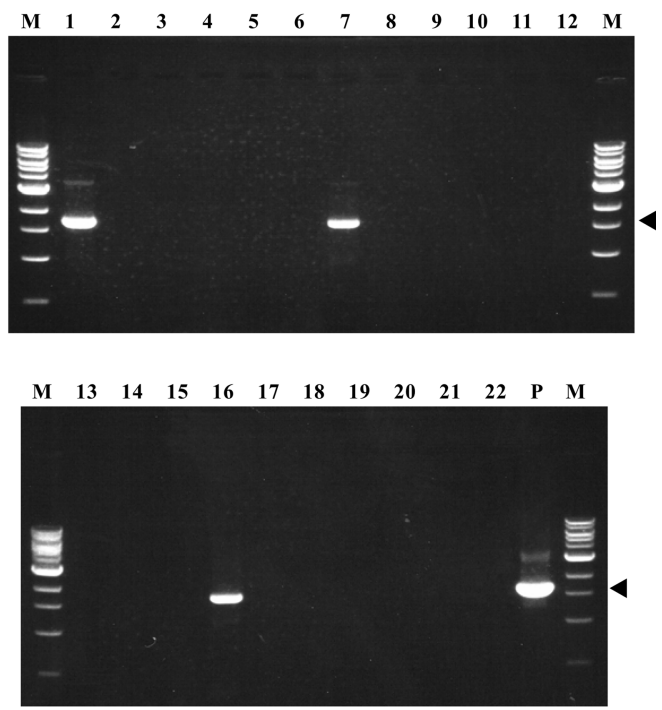

Fig. 1. PCR detection of (A) satsuma dwarf virus (SDV) and (B) citrus mosaic virus (CiMV) strains using specific primers. The 22 citrus samples collected in 2019 were detected both immunochromatographic assay and reverse transcription polymerase chain reaction (FW146 and nRV488 primer pair) test. Citrus isolates of S-58 and NG2 were positive control of SDV and CiMV strains, respectively. Expected amplified products are indicated by arrowheads. Lane M, 1 kb DNA ladder (New England Biolabs, Ipswich, MA, USA); lane P, PCRpositive control.

been widely used for SDV diagnosis in citrus orchards (Iwanami, 2010). The method is easy and rapid, and assays can be performed within the orchard. In this study, we verified the effectiveness of the ICA kit for conducting large-scale diagnosis of orchard-grown trees in Shizuoka Prefecture. The positive scores obtained by ICA in 2012 and 2019 were fully consistent with those obtained by RTPCR analysis (Iwanami, 2010). In the present study, the sensitivity of ICA was higher than that of DAS-ELISA, which missed 11 positive cases. The relative difference in sensitivity (i.e., the percentage of cases negative by DASELISA but positive by ICA) was $0.8 \%$ in $2011,0.7 \%$ in 2012, and $0.1 \%$ in 2019. All the ICA-negative samples, which were collected in a region in which SDV is widespread, were also negative by RT-PCR analysis. Thus, the results of ICA were entirely consistent with those of RTPCR.

Both DAS-ELISA and ICA have advantages and disadvantages. DAS-ELISA has been widely used for diagnosis of SDV in large-scale surveys, but it is time consuming. In the present study, when 736 samples were tested in 2012 by 5 people, it took 2 days for them to perform the assay by ICA, but 7 days to perform DAS-ELISA. The ICA kit is also easy to use in the field, but is more costly than DASELISA: it costs about 6 USD per sample, whereas DASELISA costs about 1 USD. Considering labor costs can be considerably reduced by using the ICA kit, ICA would be useful as an alternative tool for the detection of SDV.

The specificity of the ICA kit is sufficient for the detection of various SDV strains (SDV, CiMV and NIMV) (Kusano et al., 2007). Thus, ICA can be used for largescale surveys of complex populations of SDV species in citrus orchards. Here, we detected a population containing SDV and CiMV strains in Shizuoka Prefecture. Overall, it can be concluded that ICA is a useful tool for the diagnosis of SDV in large-scale surveys. Indeed, in Shizuoka Prefecture, ICA has been adopted for large-scale diagnosis since 2014 owing to its advantages, and is now widely used for routine SDV diagnosis.

This study revealed that the SDV strain is predominant in Shizuoka Prefecture; this population structure is different from that in Wakayama Prefecture, a major citrus production area, where CiMV is prevalent (Inuma and Tomimura, 2016). Most isolates tested positive by both ICA and RTPCR were identified as SDV strains. In 3 samples, RTPCR failed to detect SDV, CiMV, or NIMV, but direct sequencing using common RNA-2 sequences (Iwanami, 2010) detected CiMV in all 3 samples. These results suggest that CiMV is more diverse than SDV. To analyze CiMV diversity, more samples from citrus orchards need to be collected and analyzed. Interestingly, the 3 isolates identified as divergent CiMV were collected from the same 
citrus orchard. The coexistence of SDV and CiMV strains in the same citrus orchard indicates that such orchards would be sources of dispersal of more than one SDV strain. Further precise analysis is expected to reveal interesting genetic diversity of SDV species, including the divergent CiMV strain.

\section{References}

Azeri, T. 1973. First report of satsuma dwarf virus disease on satsuma mandarins in Turkey. Plant Dis. Rep. 57:149-153.

Clark, M. F. and Adams, A. N. 1977. Characteristics of the microplate method of enzyme-linked immunosorbent assay for the detection of plant viruses. J. Gen. Virol. 34:475-483.

Fauquet, C. M., Mayo, M. A., Maniloff, J., Desselberger, U. and Ball, L. A. 2005. Virus taxonomy: eighth report of the international committee on taxonomy of viruses. Elsevier Academic Press, San Diego, CA, USA. 1259 pp.

Ide, Y., Nunokawa, T., Shimada, S., Narahara, K., Tashiro, N. and Kuchiki, F. 2011. Development of an automatic grinding machine to homogenize many samples for enzyme-linked immunosorbent assay of plant viruses. Jpn. J. Phytopathol. 77:295-298 (in Japanese).

Inuma, T. and Tomimura, K. 2016. Strains of Satsuma dwarf virus detected on citrus trees in Wakayama Prefecture. Ann. Rep. Kansai Plant Prot. 58:107-108 (in Japanese).

Iwanami, T. 2010. Properties and control of Satsuma dwarf virus. JARQ 44:1-6.

Iwanami, T., Kondo, Y., Kobayashi, M., Han, S. S. and Karasev, A. V. 2001. Sequence diversity and interrelationships among isolates of satsuma dwarf-related viruses. Arch. Virol. 146:807-813.

Kim, D.-H., Hyun, J.-W., Lee, S.-C., Chung, S.-K. and Choi, I.-M. 2001. Study on the virus infection state of citrus of Cheju-do area and the culture of virus-free stocks. HortScience 36:607.

Kusano, N., Hirashima, K., Kuwahara, M., Narahara, K., Imamura, T., Mimori, T., Nakahira, K. and Torii, K. 2007.
Immunochromatographic assay for simple and rapid detection of Satsuma dwarf virus and related viruses using monoclonal antibodies. J. Gen. Plant Pathol. 73:66-71.

Nomura, A., Masui, H., Serizawa, S. and Ota, K. 2000. Survey of indexing for satsuma dwarf virus and citrus tatter leaf virus of citrus varieties in Shizuoka prefecture. Bull. Shizuoka Citrus Exp. Stn. 29:31-37 (in Japanese).

Shimizu, S. and Miyoshi, T. 2002. Diagnosis for viruses and viroids from citrus by reverse transcription - polymerase chain reaction. Proc. Assoc. Plant Prot. Shikoku 37:23-28 (in Japanese).

Shimomura, K. and Noguchi, Y. 2003. Sensitive detection of satsuma dwarf virus by reverse transcription polymerase chain reaction. Bull. Fukuoka Agric. Res. Cent. 22:99-102 (in Japanese).

Takahashi, Y. 1988. Serological diagnosis for plant viruses (2) Enzyme-linked immunosorbent assay (ELISA). The characteristics and technical remarks. Plant Prot. 42:88-92 (in Japanese).

Tanaka, H. and Yamada, S. 1972. Evidence for a relationship among the viruses of satsuma dwarf, citrus mosaic, navelinfectious-mottling, natsudaidai dwarf, citrus variegation, and citrus crinkly leaf. Int. Organ. Citrus Virol. Conf. Proc. 5:7176.

Thompson, J. R., Dasgupta, I., Fuchs, M., Iwanami, T., Karasev, A. V., Petrzik, K., Sanfaçon, H., Tzanetakis, I., van der Vlugt, R., Wetzel, T., Yoshikawa, N. and ICTV Report Consortium. 2017. ICTV virus taxonomy profile: Secoviridae. J. Gen. Virol. 98:529-531.

Ushiyama, K. and Ogaki, C. 1970. Studies on the Satsuma dwarf virus disease. I. Survey in the Kanagawa prefecture. Bull. Kanagawa Hortic. Exp. Stn. 18:57-65 (in Japanese).

Voller, A., Bidwell, D. E. and Bartlett, A. 1976. Enzyme immunoassays in diagnostic medicine. Theory and practice. Bull. World Health Organ. 53:55-65.

Zhou, C. Y., Zhao, X. Y., Jiang, Y. H. and He, X. H. 1990. Identification of satsuma dwarf disease of satsuma mandarin. J. Southwest Agric. Univ. 12:346-348 (in Chinese). 